\title{
Relasi, interaksi dan komunikasi interpersonal dokter-pasien dalam pelayanan kesehatan
}

\author{
Joko Fe briantoro $^{1^{*}}$ \\ ${ }^{1}$ Fakultas Kedokteran, Universitas Muhammadiyah Malang
}

\begin{abstract}
ABSTRAK
Relasi dokter-pasien didasarkan pada kualitas komunikasi dan interaksi yang baik dengan pasien, sehingga tidak hanya mampu membantu mempercepatproses penyembuhan, tetapi juga membuat pasien merasa nyaman sejak kunjungan pertama ke pelayanan kesehatan. Saatmenghadapipasien anak, kemampuan membina hubungan saling percaya dilakukan dengan sikap yang lebih terbuka, jujur dan mengerti apa yang sedang mereka rasakan. Penelitian ini bertujuan untuk melihat gambaran secara nyata tentang relasi, interaksi dan komunikasi interpersonalantara dokter-pasien dalam pelayanan kesehatan. Penelitian ini menggunakan studi deskriptif kualitatifdimana data diperolehmelalui transkrip wawancara, catatan data observasi lapangan dan dokumentasi foto. Sejumlah 7 partisipan diperoleh melalui teknik purposive-sampling pada dokter spesialis anak yang sehariharinya terbiasa melakukan relasi, interaksi dan komunikasi efektif pada pasien anak, keluarga maupun pengantarnya. Data selanjutnya dianalisis menggunakan metode Miles dan Huberman. Hasil penelitian menunjukkan tiga aspek penting terkaitrelasi, interaksi dan komunikasi interpersonalantara dokter pasien dalam hal melakukan edukasi, memberikan hiburan dan menguatkan motivasi pasien selama berada dalam pelayanan kesehatan. Komunikasi interpersonal yang efektifmembutuhkan peran dokteryang optimal sebagai komunikator untuk menyampaikan pesan kepada pasien maupun keluargaatau pengantar pasien. Selain itu, relasi komunikasi antara dokter-pasien seharusny a bersifat terapeutik terutama pada pasien yang masihberusia anak-anak sehingga mereka tidak merasa ketakutan selama berada di layanan kesehatan yang pada akhirnya berdampak pada perkembangan kesembuhan pasien.
\end{abstract}

Kata kunci: relasi; interaksi; komunikasi interpersonal; dokter-pasien

\begin{abstract}
Introduction: The doctor-patient relationship is based on good quality of communication and interaction with the patient, so that it not only can help speed up the healing process, butalso make the patient feel comfortable since the first visit to the health service. When dealing with pediatric patients, the ability to build a relationship of mutual trust is done with a more open, honest attitude and understanding what they are feeling. Aim of study: This study aims to see a real picture of the relationships, interactions and interpersonal communication between doctors and patients in health care. Method: This study uses a qualitative descriptive study where data is obtained through interview transcripts, field observation data notes and photo doc umentation. A total of 7 participants were obtained through a purposive sampling technique on pediatricians who are accustomed to engaging in effective relationships, interactions and communication with pediatric patients, families and introductors. Data were then analyzed using the Miles and Huberman method. Results and Discussions: The results showed three important aspects related to relations, interactions and interpersonal communication between patient physicians in terms of educating, providing entertainment and strengthening patient motivation while in health care. Conclusions: Effective interpersonal communication requires the optimal role of the doctor as a communicator to deliver messages to the patient or familyor patient introduction. In addition, the communication relationship between doctor and patient should be therapeutic, especially in patients who are still children so that they do not feel scared while in health care, which in turn has an impact on the development of patient recovery.
\end{abstract}

Keywords: relationship; interaction; interpersonal communication; doctor-patient

* Kores pondensi penulis:

Nama : Joko Febriantoro

Instansi: Fakultas Kedokteran, Universitas Muhammadiyah Malang

Alamat : Jl. Bendungan Sutami 188A, Malang, Jawa Timur, Telp.: +62-341-552443/+62-341-582260

Email :febriantoro@umm.ac.id 


\section{Pendahuluan}

Relasi antara dokter-pasien adalah hubungan yang terjadi secara profesional. Rasa saling percaya merupakan aspek fundamental dalam relasi ini. Ketika pasien mempercayai seorang dokter untuk menangani masalah kesehatannya, artinya pasien yakin dan percaya sepenuhnya pada dokter dalam mengelola penyakitnya. Sebagai konsekuensinya, dokter dituntut agar dapat menerapkan ilmu dan kemampuannya sesuai dengan standar dan kode etik kedokteran yang berlaku. Terdapat beberapa faktor yang dapat mempengaruhi relasi dokterpasien yaitu komunikasi, faktor sosial, budaya, latar belakang pendidikan, pengalaman sebelumnya, usia dan sikap. ${ }^{1}$

Komunikasi merupakan aspek utama dalam relasi antara dokter-pasien. Melalui komunikasi, pasien dapat menyampaikan apa yang ada di dalam pikirannya, mengungkapkan pendapat dan bersikap yang baik saat berinteraksi dengan dokter maupun petugas medis lainnya. Hal ini dapat berarti bahwa relasi dokter-pasien terjadi melalui proses komunikasi dimana terjadi hubungan timbal balik antara kedua belah pihak. Komunikasi yang dilakukan secara efektif akan memengaruhi kesembuhan pasien. $^{2}$

Relasi dokter-pasien didasarkan pada kualitas komunikasi dan interaksi yang baik dengan pasien, sehingga tidak hanya mampu membantu mempercepat proses penyembuhan, tetapi juga membuat pasien merasa nyaman sejak kunjungan pertama ke pelayanan kesehatan. Relasi dokter-pasien juga menentukan kualitas pelayanan kesehatan dan mengembangkan paradigma medis dalam pengelolaan pasien. ${ }^{3}$

Relasi, interaksi dan komunikasi interpersonal antara dokter-pasien tidak hanya dilakukan untuk memahami penyakit pasien, tetapi bertujuan agar dokter dapat lebih memahami pasien sebagai individu dengan memperhatikan kebutuhan pasien daripada kondisi penyakitnya. Hal ini juga dapat membantu pasien dalam memahami kondisi medisnya dan secara aktif mampu merawat diri mereka sendiri. Komunikasi yang efektif antara dokter-pasien dapat meningkatkan kenyamanan pasien selain faktor lainnya seperti perilaku dokter, ketersediaan informasi yang akurat, sikap empati dan kepercayaan. ${ }^{4}$

Untuk menciptakan relasi dan interaksi yang sehat antara dokter-pasien, bukan hanya faktor waktu yang diperhitungkan tetapi juga kualitas komunikasi. Pasien dapat menilai dokter melalui kemampuan dokter saat mendengarkan, memahami dan menerima keluhan yang mereka rasakan. Kemampuan dokter dalam memberikan edukasi tentang kondisi kesehatan mereka mampu membantu pasien menjadi lebih realistis dan memiliki motivasi untuk sembuh. ${ }^{5}$

Dokter harus memahami apa yang dikeluhkan oleh pasien, terutama jika yang dihadapi adalah pasien anak. Mengapa hal ini menjadi penting, karena pada umumnya komunikasi yang terjadi antara dokter-pasien terbilang singkat dimana dokter hanya menanyakan masalah pasien dalam waktu yang singkat. Seringkali pasien anak merasakan kesulitan untuk berinteraksi dengan dokter karena waktu yang singkat saat berdiskusi, padahal komunikasi efektif membantu dokter agar lebih memahami keluhan pasien.

Komunikasi memang bukan hal yang mudah, karena dokter harus mampu menggali masalah pasien secara akurat. Saat menghadapi pasien anak, kemampuan membina hubungan saling percaya dilakukan dengan sikap yang lebih terbuka, jujur dan mengerti apa yang sedang mereka rasakan. Selanjutnya anak akan merasa lebih nyaman dengan dokter dan memberikan informasi yang benar sehingga dapat membantu dokter dalam mengelola masalah kesehatan anak secara lebih tepat. Penelitian terdahulu yang dilakukan secara kualitatif terkait relasi dokter-pasien anak masihlah sedikit, sehingga penelitian ini bertujuan untuk melihat gambaran secara nyata tentang relasi, interaksi dan komunikasi interpersonal antara dokter-pasien dalam pelayanan kesehatan. 


\section{Metodologi}

Penelitian ini menggunakan studi deskriptif kualitatif dimana data diperoleh melalui transkrip wawancara, catatan data observasi lapangan dan dokumentasi foto. Metode kualitatif digunakan karena penelitian ini ingin melihat gambaran secara nyata tentang relasi, interaksi dan komunikasi interpersonal antara dokter-pasien dalam pelayanan kesehatan. Sejumlah 7 partisipan diperoleh melalui teknik purposive-sampling pada dokter spesialis anak yang sehari-harinya terbiasa melakukan relasi, interaksi dan komunikasi efektif pada pasien anak, keluarga maupun pengantarnya.

Penelitian ini dilakukan di poli anak karena pada populasi ini dokter harus lebih berhati-hati dalam melakukan komunikasi agar anak tidak mengalami trauma saat berada di layanan kesehatan. Analisis data menggunakan metode Miles dan Huberman melalui pendekatan analisis interaktif untuk menggambarkan data secara lebih sistematis dan akurat. Beberapa tahapan metode Miles dan Huberman meliputi: 1) mengumpulkan data dengan melakukan wawancara, observasi dan dokumentasi lapangan, 2) melakukan reduksi data dengan mengelompokkan, membuang data yang tidak perlu, dan melakukan pengorganisasian data sehingga dapat ditarik kesimpulan, 3) menyajikan data untuk memahami apa yang terjadi dan harus dilakukan pada hasil yang diperoleh, dan 4) membuat kesimpulan secara terbuka. ${ }^{6}$ Penelitian ini menggunakan triangulasi metode dengan mengkaji ulang data yang diperoleh dengan sumber data yang sama melalui metode pengumpulan data yang berbeda. Pengkajian ulang selanjutnya dilakukan pada hasil waw ancara, data observasi dengan partisipan.

\section{Hasil dan Pembahasan}

Berdasarkan hasil wawancara pada sejumlah partisipan tersebut diperoleh tiga aspek penting dalam hal relasi, interaksi, komunikasi interpersonal antara dokter-pasien:

\section{Relasi, interaksi, komunikasi interpersonal} dalam melakukan edukasi

Edukasi merupakan hal penting dalam relasi, interaksi dan komunikasi interpersonal dokter-pasien. Dalam penelitian ini dipandang bahwa komunikasi interpersonal yang terjadi digambarkan seperti edukasi yang dilakukan oleh seorang guru kepada muridnya. Hal ini dapat terlihat pada bentuk relasi yang terjadi dimana dokter berperan sebagai guru pada pasien.

Peran sebagai guru pada pasien digambarkan saat dokter memberikan edukasi tentang penyakit pasien melalui penegakan diagnosa, penetapan rencana tindakan maupun pengobatan dengan melibatkan pasien dalam pengambilan keputusan. Namun demikian, pasien dapat menyetujui atau menolak rencana tindakan yang akan dilakukan dikarenakan faktor lainnya seperti kecukupan biaya dan lamanya rencana tindakan yang akan diberikan.

Peran dokter lainnya tampak ketika menerangkan penyakit pasien. Dalam hal ini pasien dianggap sebagai gambaran kehidupan sehari-hari yang dihadapi oleh seorang dokter, sehingga melakukan edukasi kepada pasien merupakan kewajibannya. Dokter lebih menyukai pasien yang mudah diajak dalam berkomunikasi, memiliki sikap yang terbuka, dan menerima masalah kesehatannya.

Relasi, interaksi, komunikasi interpersonal dalam melakukan edukasi adalah pertukaran informasi dari komunikator pada komunikan dalam hal pemberian edukasi. Saat wawancara, peneliti menanyakan tentang apa dan bagaimana yang dilakukan dokter spesialis anak pada pasiennya agar tidak merasa takut dengan dokter. Melalui wawancara tersebut diintepretasikan bahwa seorang dokter bukan sosok yang seharusnya ditakuti anak seperti yang seringkali dijadikan sebagai ancaman orang tua untuk menakuti anak agar anak lebih patuh. Partisipan menunjukkan tentang kredibilitas dokter yang mampu memberikan penjelasan, sikap yang lebih bersahabat sehingga tidak takut dengan dokter dan memiliki gambaran yang baik tentang dokter. Berikut 
adalah kutipan hasil wawancara dengan partisipan:

"ee...ya harus ngertiusianya dahulu... bisa diajak berkomunikasi nggak, ...kalo bisa diajak ya kami berikan penjelasan dengan mengenalkan diri, tidak menakut-nakuti... bahkan kamimemposisikan sebagai orang yang bersahabat ...”(PI)

"ya penting itu......menunjukkan bahwa dokter bukan sosok untuk ditakuti....saya lebih mengajak komunikasi ....menghibur..... berinteraksi....dan sebagainya."(P2)

Partisipan berusaha menunjukkan bahwa sosok dokter seharusnya tidak dipandang sebagai orang yang ditakuti. Hal ini dilakukan untuk merubah pemikiran masyarakat bahwa dokter adalah sosok yang bersahabat dan bisa membantu menyembuhkan kondisi pasien. Relasi, interaksi dan komunikasi interpersonal dokter-pasien dalam hal edukasi pada pasien adalah dengan mengenalkan dokter sebagai sosok yang tidak menakutkan.

Komunikasi yang efektif merupakan prioritas utama dalam pelayanan dokter pada pasien. Dokter diharapkan mampu menjadi komunikator yang baik selama proses komunikasi. Komunikasi dilakukan dengan memberikan informasi yang akurat agar tidak menyebabkan salah persepsi. Hal ini dapat terlihat pada wawancara dengan partisipan sebagai berikut:

\section{“...kami...dokter harus memiliki kemampuan dalamberkomunikasi kepada pasien....memberikan edukasi...pada pasien tentang penyakitnya ....kalo sampai salah informasi, akan fatal..."(P1)}

"untuk pasien ini...kita harus bisa jadi teman mereka, bahkan jadi guru....harus bisa memperkenalkan diri....bisa bersahabatagarmereka tidak takut... juga mengenalkan alat-alat yang kita pakai....seperti stetoskop, jarum suntik... agar mereka mau menerima...dan tidak rewel...."(P2)
Hasil wawancara menunjukkan gambaran seorang dokter anak yang menjadi teman ataupun guru dimana dalam hal ini dokter harus memiliki sikap yang lebih bersahabat dengan pasien anak melalui komunikasi efektif. Memberikan pemahaman anak terhadap alat-alat yang digunakan akan mengurangi rasa ketakutan anak terhadap dokter. Adapun kendala yang dihadapi dokter saat melakukan komunikasi dengan keluarga ataupun pengantar pasien tampak pada jawaban dari partisipan sebagai berikut:

"Biasa sih....akan bingung menerima penjelasan dari kami kalo pake....bahasa medis..." $(P 3)$

“....yang jadikendala itu ... bahasa medis. ya kami harus mengulangnya berkalikali..."(P4)

Kendala yang dihadapi dokter dalam melakukan komunikasi yaitu penggunaan bahasa medis. Dokter harus memiliki kemampuan untuk menjelaskan dengan menggunakan bahasa lebih mudah dimengerti. Proses penyampaian pesan merupakan salah satu indikator penting yang menunjang keberhasilan komunikasi. Pesan berperan penting dalam menjembatani maksud yang ingin disampaikan oleh komunikator pada komunikan.

Begitupun yang terjadi pada relasi, interaksi dan komunikasi interpersonal dokter dalam melakukan edukasi pada pasien. Sebagai seorang komunikator yang baik, dokter diharapkan mampu memahami kepada siapa dan c ara yang baik dalam menyampaikan pesan pada pasien sebagai komunikan. Dalam melakukan edukasi, perlu adanya pemaparan tentang peran dokter dan gambaran dokter sebagai sosok yang tidak menakutkan anak sehingga mereka menjadi lebih kooperatif dan tidak mengalami trauma selama berada di pelayanan kesehatan.

Dokter dituntut memiliki profesionalisme yang tinggi dan menjalankan profesi sesuai dengan keahlian yang dimiliki yaitu menyembuhkan pasien dengan melakukan komunikasi efektif dalam menjelaskan kondisi 
pasien dan menggunakan bahasa yang lebih mudah dipahami. Hal ini dilakukan karena dokter juga berperan sebagai seorang konsultan tentang penyakit pasien. Komunikasi medis dokter dilakukan dalam bentuk lisan dan tertulis untuk mendokumentasikan apa saja yang sudah dilakukan dokter dalam menangani penyakit pasien. Dokumentasi dilakukan untuk meningkatkan keselamatan pasien dan mencegah tuduhan malpraktik.

Dengan demikian, dokter harus bisa melakukan edukasi baik secara langsung maupun tidak langsung kepada pasien, keluarga maupun pengantarnya melalui tahapan perkenalan, anamnesis, maupun melalui penjelasan yang akurat untuk mengurangi kesalahpahaman pasien.

\section{Relasi, interaksi, komunikasi interpersonal dalam memberikan hiburan}

Seringkali kita mendengar bahw a rumah sakit, petugas medis ataupun dokter sebagai sebuah idiom kata yang bersifat menakutkan, seperti..."kalau nakal nanti disuntik dokter lo ya..." dan sebagainya. Hal ini selanjutnya menjadi stimulus yang negatif dalam pemikiran anak anak dimana dokter dianggap sebagai sosol yang menakutkan. Dalam wawancara, partisipan ditanyakan tentang upaya mereka saat menghadapi pasien yang rewel dan menangis.

\footnotetext{
"Ya ... kitamenenangkannya, lagian ini juga sudah resiko seorang dokter anak ..... harus bisa bersikap baik.....biasanya....mengajak ngobrol...mengalihkan perhatiannya ....di “kudang” ya mas, biar dia ga takut dan nangis...ya sama keluarganya juga bantu.. "(P2)

“...ya dikudang...dihibur biar ga nangis....baru periksa pelan-pelan ....ya reflek aja .... dokter juga harus ngerti cara dan gimana komunikasi dengan anak..." (P5)
}

Dokter dapat bekerjasama dengan keluarga atau pengantar pasien anak agar lebih merasa tenang, karena anak yang rewel ataupun saat diperiksa menjadi hambatan tersendiri selama proses pemeriksaan. Beberapa upaya untuk meningkatkan kenyamanan anak digambarkan sebagai berikut:

"kalau polianak...rumah sakit mendesain poli agar lebih disukai oleh anak-anak.... ada gambar kartun...supaya anak bisa teralihkan perhatiannya saat diperiksa..."(P6)

“...ruangan diberi gambar kartun yang sesuai yang disukai anak....agar mereka senang..." $(P 7)$

Rumah sakit juga meningkatkan kenyamanan pasien anak dengan memberikan desain khusus pada poli anak. Hal ini menunjukkan bahwa relasi, interaksi, komunikasi interpersonal dalam memberikan hiburan sudah tercipta dengan baik. Desain ruangan praktik dokter juga sudah memberikan kesan menyenangkan dengan adanya gambar kartun.

Relasi, interaksi, komunikasi interpersonal dalam memberikan hiburan dapat diintepretasikan sebagai sebuah interaksi dokter dan pasien dalam konteks hiburan. Dokter anak melakukan upayanya untuk menghibur pasien saat mereka rewel, atau menangis. Melakukan komunikasi secara non verbal dengan menghibur anak membuat anak tidak rewel dan takut dengan dokter.

Untuk mengurangi kesan menakutkan, baju seragam dokter yang serba berwarna puth juga dapat diganti dengan menggunakan baju yang lebih santai, mendesain ruangan sedemikian rupa untuk mengalihkan perhatian anak, membuat anak lebih familiar dengan alat yang digunakan dokter, dan lain sebagainya.

\section{Relasi, interaksi, komunikasi interpersonal dalam menguatkan motivasi}

Selain melakukan edukasi dan memberikan hiburan, dokter diharuskan mampu memberikan motivasi pada pasien untuk meningkatkan kesembuhan anak. Berikut adalah hasil waw ancara dengan partisipan: 
"yaa...biasanya lebih memberikan perhatian pasien.......memberikan semangat agar jangan menyerah....(P2)

Menguatkan motivasi dilakukan melalui pesan yang disampaikan oleh dokter. Biasanya pesan ini diberikan setelah dokter selesai menjelaskan hasil pemeriksaan pada pasien. Motivasi yang diberikan dapat meningkatkan semangat pasien sehingga dapat membantu mempercepat proses kesembuhan pasien. Dokter dapat memberikan dorongan pada keluarga pasien agar lebih sabar dan telaten dalam merawat pasien.

Relasi, interaksi, komunikasi interpersonal dalam menguatkan motivasi dilakukan dengan meningkatkan semangat pasien melalui sikap yang terbuka dan ramah. Studi sebelumnya menjelaskan bahwa sikap keterbukaan dapat menstimulus pasien untuk menceritakan masalahnya secara lebih nyaman dan tidak ada yang ditutupi. Dalam hal ini berarti komunikasi seharusnya terjadi secara timbal balik dimana baik dokter dan pasien harus bisa bersikap terbuka dalam melakukan komunikasi. ${ }^{7}$ Adanya umpan balik merupakan kelanjutan dari sebuah proses komunikasi sehingga pasien akan mengikuti anjuran dokter. ${ }^{8}$

Dalam membina relasi dengan pasien, dokter diharapkan mampu bersikap hangat, terbuka, jujur, menghargai, menjaga privasi, meningkatkan otonomi pasien dan peduli pada pasien. Interaksi dilakukan dengan menjaga kontak mata, menjadi pendengar aktif dan menggunakan bahasa yang lebih mudah dipahami pasien untuk meningkatkan partisipasi pasien dalam proses kesembuhannya. ${ }^{9}$ Relasi yang terjadi antara dokter-pasien adalah relasi yang saling membutuhkan dan bersifat terikat karena adanya kecenderungan individu yang sakit akan melakukan pengobatan ke dokter. Begitupula saat individu dalam kondisi sehat, dokter tetap dibutuhkan untuk memberikan upaya kesehatan yang bersifat promotif dan preventif. Sehingga komunikasi yang disampaikan oleh dokter haruslah tepat agar tidak terjadi kesalahpahaman. Melalui relasi, interaksi, komunikasi interpersonal dokter- pasien yang baik, maka pasien akan mencapai status kesehatan yang optimal. ${ }^{1,10}$

\section{Kesimpulan}

Komunikasi interpersonal yang efektif membutuhkan peran dokter yang optimal sebagai komunikator untuk menyampaikan pesan kepada pasien maupun keluarga atau pengantar pasien. Selain itu, relasi komunikasi antara dokter-pasien seharusnya bersifat terapeutik terutama pada pasien yang masih berusia anak-anak sehingga mereka tidak merasa ketakutan selama berada di layanan kesehatan yang pada akhirnya berdampak pada perkembangan kesembuhan pasien.

\section{Ucapan Terima Kasih}

Penulis mengucapkan terima kasih yang sebesar-besarnya kepada Fakultas Kedokteran, Universitas Muhammadiyah Malang atas dukungannya selama penulisan artikel ini.

\section{Referensi}

1. Setyaw an FEB. Komunikasi Medis: Hubungan Dokter-Pasien. Jurnal Berkala Ilmiah Kedokteran dan Kesehatan [Internet]. 2017 [cited 2020 Jun 1];1(4):51-57. Available from: https://jurnal.unimus.ac.id/index.php/APKK M/article/view/3282.

2. Prasanti D. Komunikasi Terapeutik Tenaga Medis tentang Obat Tradisionalbagi Masyarakat. MediaTor [Internet]. 2017 Jun [cited 2020 Jun 1];10(1):53-64. Available from:

https://media.neliti.com/media/publications/ 154026-ID-komunikasi-terapeutik-tenagamedis-dalam.pdf.

3. Tanveer F, Shahid S, Hafeez MM. Impact of Doctor's Interpersonal Communication Skill on Patient's Satisfaction Level. Isra Medical Journal [Internet]. 2018 Sep [cited 2020 Jun 1];10(5):306-309. Available from: https://ww w.researchgate.net/publication/32 5603811.

4. Pasaribu BS, Aulia D, Rochadi RK. Effect of Doctor's Interpersonal Communic ation on 
Patient Satisfaction at Royal Prima General Hospital Medan. International Journal of Research and Review [Internet]. 2019 Nov [cited 2020 Jun 1];6(11):162-187. Available from:

https://www.ijrrjournal.com/IJRR_Vol.6_Iss ue.11_Nov2019/IJRR0023.pdf.

5. Curković M, Milošević M, Borovečki A, Mustajbegović J. Physicians' interpersonal relationships and professional standing seen through the eyes of the general public in Croatia. Patient Prefer Adherence [Internet]. 2014 Aug [cited 2020 Jun 1];8:1135-42. Available from: https://doi/org/10.2147/PPA.S65456.

6. Ilyas I. Pendidikan Karakter Melalui Homeschooling. Journal of Nonformal Education [Internet]. 2016 [cited 2020 Jun 1];2(1):91-98. Available from: https://journal.unnes.ac.id/nju/index.php/jne/ article/view/5316.

7. Liow D, Himpong M, Waleleng G. Peran Komunikasi Antara Dokter dan Pasien dalam Pelayanan Medis di Klinik Reci Desa Sinisir Kecamatan Modoinding. Acta Diurna Komunikasi [Internet]. 2020 [cited 2020 Jun 1];2(1):1-14. Available from: https://ejournal.unsrat.ac.id/index.php/actadi urnakomunikasi/artic le/view/27074.

8. Manoppo HB, Mewengkang NN, Koagouw FVIA. Studi Komunikasi Interpersonal Pasien Rumah Sakit Bethesda Tomohon Instalasi Rawat Jalan Poliklinik Kandungan/Kebidanan. Acta Diurna Komunikasi [Internet]. 2014 [cited 2020 Jun 1];3(2):1-8. Available from: https://ejournal.unsrat.ac.id/index.php/actadi urnakomunikasi/article/view/5141.

9. Larasati TA. Komunikasi Dokter-Pasien Berfokus Pasien pada Pelayanan Kesehatan Primer. Jurnal Kedokteran Universitas Lampung [Internet]. 2019 [cited 2020 Jun 1];3(1):160-166. Available from: https://juke.kedokteran.unila.ac.id/index.php /JK/article/view/2221.

10. Panitra TD, Tamburian HHD. Komunikasi Antarpribadi Dokter Dengan Pasien dalam
Membantu Penyembuhan Pasien di Klinik Cendana. Koneksi [Internet]. 2019 [cited 2020 Jun 1];3(1):71-76. Available from: http://dx.doi.org/10.24912/kn.v3i1.6147. 